\title{
Problems and Prospects of Reforming the Russian Criminal Procedure Legislation
}

\author{
Alla V. Vereshchagina \\ Andrey V. Dovbysh \\ Vladivostok State University of Economics and Service \\ Email: eldirect@mail.ru,vereschagina_alla@mail.ru
}

\section{Doi:10.5901/mjss.2015.v6n3p306}

\section{Abstract}

The countdown of modern judicial reform in Russia has been conducted since the adoption by the Supreme Soviet of the RSFSR the Decree "On the Concept of judicial reform in the RSFSR" (The resolution of the SC of the RSFSR, 1991). However, the duration of the ongoing reforms has not led to the resolution of problems in regulation of criminal procedure. Established in the RF CCP of 2001 dualistic model of criminal procedure is constantly adjusting, while introduced in the criminal procedure law changes don't improve it, but rather mislead the law enforcer. Fundamental to the criminal procedure reform, in our opinion, is the question of the definition of the essence of criminal procedure, depending on the solution on want it is necessary to build logic of transformations. It seems that we should return to the original understanding of criminal justice as a system of guarantees of the rights and freedoms of the individual, in respect of which a criminal prosecution, and on the basis of this approach to design as a separate institutes of criminal procedure, and in General of the Russian criminal procedural form. It seems that we should return to the original understanding of criminal procedure as a system of guarantees of the rights and freedoms of the individual, in respect of which a criminal prosecution, and on the basis of this approach to design a separate institutes of criminal procedure, and in general the Russian criminal procedural form.

Keywords: criminal procedure, reform, legislation, human rights safeguards.

\section{Introduction}

Since the adoption in 2001 of the Criminal procedure code of the Russian Federation (Criminal procedure code of the Russian Federation, 2001) a numerous additions and changes, the contents of which are often mutually exclusive in nature, are constantly made in it. That "inflammation", in the words of M. M. Speranskiy, with which the legislator amends the criminal procedure law, indicates two things: the quality of the criminal procedure law and the lack of clarity in the question about the future direction of its reformation.

As for the quality of the criminal procedure law, this normative legal act is replete with lack of consistency to the regulation of certain institutions (for example, the language of criminal procedure), consolidation of redundant criminal procedural safeguards (in particular, the Russian formulation of the principle of presumption of innocence), the presence of gaps, reference standards, etc.

With regard to the definition of the concept of development of criminal procedure legislation, the situation is even more complex, because the supporters of the two main approaches to the understanding of the purpose of criminal procedure take an antagonistic position and are not inclined to compromise.

In the proposed publication an attempt is made to explain the author's approach to the regulation of the criminal procedure law, in the basis of which must be a liberal understanding of the purpose of the criminal procedure legislation as safeguards of the rights of criminal persecuted person.

The presented study is based on general philosophical method, the content of which includes the principles of objectivity, consistency, historical and dialectical contradictions, as well as the methods of formal logic, the legal-dogmatic method is used (interpretation and evaluation of the regulatory definitions), and also comparative legal method (in particular comparison of international legal standards and normative models of some of the Russian criminal procedure principles).

\section{Literature Review}

About inconsistency of correction of the criminal procedure law ( its private institutions) wrote many (I.A. Antonov, 2014; 
L.A. Voskoboeva, 2014; Y.A. Lyakhova, 2010; A.Sh. Magomedov, 2013; T.K. Ryabinina and A.A. Kozyavin, http://eizvestia.isea.ru/reader/article.aspx?id=19971. DOI: 10.17150/2072-0904.2015.6(1).21, 2015; Karabulatova, I.S., DOI: 10.5829/idosi.mejsr.2013.17.06.12262, 2013; and A.A. Kozyavin, 2010). This is, according to most researchers, is because the legislator has not defined the conceptual foundations of the criminal procedure reform. There are two main concepts of entity criminal justice in the literature: 1) the criminal process is a means of fighting crime and 2) the criminal process is a set of human rights guarantees, in respect to which a criminal prosecution is realized. Proponents of the first position (T.N. Ostrovskaya; A.A. Kozyavin, 2010; Y.A. Lyakhov; and T.K. Ryabinina and A.A. Kozyavin, http://eizvestia.isea.ru/reader/article.aspx?id=19971. DOI: 10.17150/2072-0904.2015.6(1).21, 2015) see the essence of the criminal process in the fight against crime, and, as a consequence, consider appropriate to the essence the concept of inquisitorial procedure.

At the same time, proponents of the second position (I.A. Antonov, 2014; L.A. Voskoboeva; and I.S. Dikarev, 2013) hold the view according to which criminal prosedure legislation should evoluate toward the adversarial criminal process and along the way and the essence of the criminal process lies in ensuring procedural safeguards of the rights and freedoms of the individual, in respect of which a criminal prosecution is carried out.

So, I. S. Dikarev in his article, "criminal procedure: "a quiet revolution" was replaced by the reaction" in the course of reasoning about the prospects of granting the court authority to return the criminal case to the prosecutor for re-training it on the more serious offence" comes to the conclusion that "laying ... on the court the duty to monitor the object or the amount of the claims of the prosecution makes him responsible for the results of the activity which that party provides. Providing such assistance to the bodies of preliminary investigation and public prosecution, the court inevitably becomes the prosecution that destroys the competitive structure of the legislation" (I.S. Dikarev, 2013).

\section{Findings and Research}

As noted earlier, at the literature review on the topic of this publication, the main reason of problematical character, contradictions and duality of development of the criminal procedural legislation of the Russian Federation lies in the lack of consensus about the nature of the criminal-procedural activity - whether it is a way of dealing with crime (Soviet tradition) or system of human rights guarantees, in respect of which criminal prosecution is carried out (a priori assignment of the criminal process).

The consequence of this duality is the fact that more than 10 years of validity of the CCP of the RF of 2001 in his text 2664 amendments by adopting 148 Federal laws on amendments were made (L.A. Voskoboeva, 2014). However, changes in the CCP of the RF are inconsistent, and sometimes contradictory, simultaneously reinforce adversarial and inquisitorial components. Enforcement, in contrast, represents a purely inquisitorial results that fit into the mainstream of constitutional ideology and concepts of the criminal procedure law (Review amended of the CCP, refer to: Vereshchagina A.V., 2011) only in protecting the rights and freedoms that had been done from crime.

In the preparation of the current criminal procedure law a unified and clear position of the legislator on the issue of the essence of the criminal process has not been developed. This may explain the presence in the original edition of mutually exclusive provisions. For example, the duality of the legal formula for the purpose of criminal legislation, under which in criminal proceedings at the same time are protecting the rights and legitimate interests of the victim and the accused (suspect, defendant) (Art. 6 CCP of the RF). Or the preservation of a system of criminal procedural steps established in the Soviet period, which was combined with the attempt of gradual implementation of the adversarial principle. This was expressed in a clear diversification of procedural functions between subjects of enforcement; in waiver of procedural supervision of the prosecution before the court and the Institute of returning the criminal case by the court for further investigation; in changing of requirements to the content of the criminal information; in minimization of the use in the stage of the trial of derivative evidence, etc.

Laid dualistically purpose of criminal legislation, lobbying some of the usual provisions of the law enforcer has caused the inconsistency in introduced in the criminal procedure law changes. For example, on the one hand the Soviet Institute of returning the criminal case for additional investigation is restoring (Art. 237 CCP of the RF). On the other, the requirement of the validity of the measure of preventive detention is specifying (p.1 Art. 108 CCP of the RF).

The ambiguity of the purpose of criminal legislation entails the variability of the behavior of a law enforcer. In such a situation always dominates one aspect of law enforcement, in this case, inquisitorial, customary, prevailing in the Soviet time, when in the framework of criminal legislation is as thought happening the crime control and the allegedly protection of society and the victim from criminal assaults. We in the above statement used the word "allegedly" not randomly (S.I. Ozhegov, 1990), which indicates the ambiguity of such understanding of the criminal process.

In this regard, it should be recalled that the conceptual basis of the Criminal procedure code of 2001 is the 
Constitution of the Russian Federation. So, part 1 of article 1 of the CCP expressly speaks about the derivativeness of the criminal procedure regulation by constitutional norms. The determinacy of the purpose of criminal legislation by ideology of this act expresses in terms of the recognition of the rights and freedoms of the individual as the highest value in the Russian Federation (Art. 2 of the Constitution of RF, Art. 6 of the CCP of the RF). In addition, the article 18 of the Constitution of the Russian Federation continues the idea of the article 2 of the Constitution, declaring the rights and liberties of man and citizen as the meaning and essence of laws, and establishes that the rights and freedoms determine the activities of legislative and executive state authorities of the Russian Federation. (The Constitution of the Russian Federation, 2008)

The inextricable link between the RF Constitution and the criminal procedure law was repeatedly noted many times (A.V. Vereshchagina, 2003; A.V. Vereshchagina, 2004; and A.V. Vereshchagina, 2009). It would seem that such an understanding of the role and importance of the Constitution of the Russian Federation for criminal procedure regulation should improve the quality of enforcement, the criteria to resolve complex, controversial issues of which was the priority of the rights and freedoms of personality.

A priori and the only essence of criminal legislation is the recognition of the criminal process, with all the guarantees of individual rights, to which the state has criminal legal claims. In the framework of criminal legislation, which is conducted on behalf and in the interests of society and the state, i.e. the public interests, the rights of a specific individual against whom the crime is committed, i.e., the victim, are protected only indirectly, because the suspect (the accused, the defendant) may have violated the criminal law prohibition. The probability of violation of criminal law ban by a specific person is most clearly manifested in the principle of presumption of innocence, i.e., the state recognizes that the fact of belonging of the person to committing crimes must be set within the framework of established by the law procedure, the violation of which is unacceptable.

A different understanding of the essence of the criminal legislation, i.e. as a means of crime control and protecting the rights sufferer from crimes is harmful. First, before any authority an unreachable goal is placing. Crime is inherent to any society, and therefore it is impossible to overcome.

Secondly, the scale of the problem (L. Kirsanova, and O. Korotina, 2014) is reducing. Fighting crime is a national problem. The higher is socio-economic relations, which provide a certain level of wealth, increased funding of state institutions involved in implementation of social programs, in fighting crime and so on, the more successful is the fighting crime.

Thirdly, the recognition of the criminal process as the method of protection of the victim and the associated with it understanding of the broad procedural capacities of the injured to influence the movement of criminal cases (Note 1) is contrary to the public nature of the criminal-procedural activity. This activity is carried out on behalf of the state by special authorized entities. Nasty understanding transforms the public nature of the Russian legislation to private-actional, supposing the bearing of the burden of a criminal prosecution by a private individual. In this connection the question arises: why do we need the bodies of pre-trial proceedings and prosecution, if the victim is endowed with extensive procedural opportunities to influence the process?!

Fourth, the understanding of the criminal process as a means of fighting crime atrophies the activities of the bodies, engaged in the operational-search activity, whose main task is the prevention of crime, detection of facts of crime, and their disclosure.

Fifthly, this leads to the prevalence of inquisitionist enforcement not only in pretrial proceedings, but in the trial stages. So, for the first half of 2014, by the courts of general jurisdiction was made just 2680 acquittals for a total 352700 sentences (i.e., the number of acquittals was only $0.75 \%$ of total convictions), for 2013 , this rate is $0.74 \%$ (5624 acquittal at made 761379 sentences) (The website of the Judicial Department under the SC of the RF, http://www.cdep.ru/ index.php?id=79, 2015). Presented figures clearly indicate the absence of a court dispute about the law and the beginning of the adversarial criminal process. The role of the modern Russian court is to confirm the legality and validity of the materials of the preliminary investigation presented in court by the prosecution. It should be recalled that preliminary investigation agencies receive these materials under the inquisitorial procedure, when the implementation of the procedural rights of the defence depends on the decision of the representatives of the prosecution.

Sixthly, the disproportion between the declaration of adversarial system and inquisitionist of enforcement contributes to the cultivation of legal nihilism (S.F. Litvinova, 2013).

\section{Conclusion}

The situation in the criminal process involves the necessity of making decisions that would have streamlined normative regulation and enforcement. There are many propositions, which are submitted by researchers, they are from the 
conceptual (the need to define the essence of criminal justice) to private (improving specific regulations) (Note 2). In General, agreeing with the fact that frequent changes should be based on the specification of the essence in criminal proceedings, we allow ourselves to express the following considerations:

1. The basis of the criminal procedure reform must be an understanding of the criminal process as a set of human rights guarantees, in respect of which a criminal prosecution is carried out.

2. The implementation of the criminal-procedural activity for each crime should be abandoned. Disclosure issues should be handled by the agencies carrying out the operative-investigative activity, and not by the bodies involved in the preparation of materials for the court.

3. To transform the system of criminal procedural stages, by abolishing the stage of excitation of criminal case and reducing pre-trial preparation materials. It is quite likely will reduce the number satisfied by the European court of human rights complaints, in connection with the violation of the right to access to justice.

4. In pretrial proceedings, the implementation of the principle of adversarial proceedings, including through the approval of the defense to participate in the investigative actions taken not only with the suspect (accused) must be extended. This minimizes doubts as submitted to the court evidentiary material and gives no consideration to the use of derivative evidence in the trial.

5. To consistently hold public beginning in the regulation of the criminal process to minimize the impact on the victim movement of the criminal case.

\section{References}

The resolution of the SC of the RSFSR from 24.10.1991 N 1801-1, 1991. "On the Concept of judicial reform in the RSFSR" / Vedomosti DNS and SC of the RSFSR". - No. 44.- Art. 1435.

Criminal procedure code of the Russian Federation dated 18.12.2001 No. 174-FL, 2015. // collected legislation of the Russian Federation.-№ 52 (p. I)-Art.4921.

Antonov, I.A., 2014. Criminal procedure reform: the retreat from conceptual provisions and frustration//Bulletin of the Krasnodar University of the Ministry of internal Affairs of Russia.№ 4 (26). pp. 74-79.

Voskoboeva, L.A., 2014. Reform of the criminal justice is continuing: if to know the direction // the Bulletin of the legal Department of the southern Federal University. №2 (2). pp. 73-79.

Lyakhova, Y.A., 2010. Priorities legal procedural lawmaking//State and law. No.8. pp. 43-48.

Magomedov, A.Sh., 2013. Failures of the legislator in reforming the preliminary investigation//Historical, philosophical, political and legal sciences, Culturology and study of art. Issues of theory and practice. №4(30). pp.117-119.

Ryabinina, T.K. and Kozyavin A.A., 2015. The results of the judicial reform in Russia of the XIX and XXI centuries and their role in solving the problems of the limits of judicial proceedings in the criminal process//proceedings of the Irkutsk state economic Academy (Baikal state University of Economics and Law).-V.6. №1. pp. 21-28. (URL : http://eizvestia.isea.ru/reader/article.aspx ?id=19971. DOI: 10.17150/2072-0904.2015.6(1).21).

Kozyavin, A.A., 2010. The use of in-court testimony of the witness and the victim received in pretrial proceedings, as the problem of adversarial criminal process // State and law. 2010. №8. pp. 49-54.

Dikarev, I.S., 2013. Criminal procedure: "a quiet revolution" was replaced by the reaction. / / Vestnik of Volgograd state University. Series 5: Law. № 3. pp. 98-103.

Voskoboeva, L.A., 2014. Reform of legal justice is continuing: if to know the direction // the Bulletin of the legal Department of the southern Federal University. № 2 (2). pp. 75-79.

Review amended of the CCP, refer to: Vereshchagina A. V. Century Review of some changes in the code, 2011. I/Law and procedure in the XXI century: continental experience and prospects: collected scientific articles. senior /Sib. Feder. University so the Jural. Inst.: resp.ed. T. V. Sakhnova. Krasnoyarsk: SFU, pp. 327-334.

Ozhegov S.I., 1990. Dictionary of Russian: 70000 words /Ed. by N. Y. Shvedova. 22nd ed., wiped. - M.: Russ. lang. pp. 944.

The Constitution of the Russian Federation (adopted by popular vote 12.12.1993 (taking into account amendments made by the Laws of the RF on amendments to the Constitution of the RF of 30.12. 2008 №6-FCL, from 30. 12. 2008 No. 7-FCL, from 5.02.2014 No. 2-FCL, from 21.07.2014 No. 11-FCL)//collected legislation of the Russian Federation.in 1993.-№-Art. 4398.

Vereshchagina, A.V., 2003. Novels of the Criminal procedure code of the Russian Federation: a conceptual aspect, the Journal of Russian law. №10. pp. 24-30.

Vereshchagin, A.V., 2004. Constitutional foundations of the criminal procedure legislation of the Russian Federation//Comparative constitutional review. №4. pp.182-190.

Vereshchagin, A.V., .2009. the Constitution of the Russian Federation as a basis for designing procedural status of the subjects of the stage of excitation of criminal case//the Constitution of the Russian Federation and the development of modern statehood (the 15th anniversary of the Constitution of the Russian Federation): the book of abstracts of the International scientific-practical conference, Saratov, 3-4 October 2008)/ editorial Board.: O. S. Rostov (resp. as amended), and others; Saratov, SEI HPT "SSAL". pp.228-229.

Karabulatova, I.S., 2013. The Problems of Linguistic Modeling of New Eurasian Linguistic Personality in Multilinguistic and Mental 
Environment (By Example of Onomasphere)// Middle-East Journal of Scientific Research 17 (devil): 791-795, 2013.ISSN 19909233.๑ IDOSI Publications. DOI: 10.5829/idosi.mejsr.2013.17.06.12262.

Court statistics. The website of the Judicial Department under the Supreme Court of the Russian Federation.URL:// http://www.cdep.ru/ index.php?id=79 (date of access: 12.03.2015).

Litvinova, S.F., 2013. Interaction of law and mentality // Historical, philosophical, political and legal Sciences, Culturology and study of art. Issues of theory and practice. № 3-2. pp. 137-140.

Kirsanova, L., and Korotina O., 2014. On the Contents of the Protest Conscience in Russia. Wolrd Applied Sciences Journal 31(5): 930934. 